\title{
Pengaruh Dimensi Eksternal Persepsional terhadap Kualitas Layanan Fakultas di Universitas Lampung
}

\author{
Siti Juriyah ${ }^{1}$, Yulianto ${ }^{2} \&$ Noverman Duadji $^{3}$ \\ 1, 2, \& 3) Fakultas Ilmu Sosial dan Ilmu Politik \\ Universitas Lampung, Indonesia \\ ${ }^{1}$ Corresponding email: siti.juriah@staff.unila.ac.id
}

\begin{abstract}
This study aims to see the effect of dimension of the external perception that includes tools of service, color of service color, uniqueness or stimulus contrast, individual style to attract attention, and moves or service techniques of both partial or simultaneous service made by employees in the Medical Doctor Faculty of Lampung University. This study applied correlational design that used questionnaire to collect data. Sample was recruited by $10 \%$ from 771 students of Medical Doctor allowing 91 selected at stratified random sampling. Data were analyzed using inferential statistics of linear regression. Hypothesis was tested using SPSS version 19.0. Results show all hypotheses are rejected concluding that there is a significant effect among tools of services, color of services, uniqueness or stimulus of contrast, individual attraction, moves or techniques of services partially and simultaneously.
\end{abstract}

Keywords: tools, color, uniqueness, individual style, moves, service quality.

\section{PENGANTAR}

Kualitas layanan dapat diketahui dengan membandingkan ekspektasi pelanggan untuk layanan ideal dengan kemampuan institusi untuk memberikan layanan berkualitas. Semakin tinggi kemampuan lembaga untuk memenuhi harapan pelanggan, semakin tinggi pula tingkat kepuasan pelanggan. Sebaliknya semakin rendah kemampuan lembaga untuk memenuhi harapan pelanggan, semakin rendah pula kepuasan pelanggan.

Layanan yang berkualitas kepada pelanggan harus selalu menjadi moto masingmasing institusi, sehingga pelanggan mendapatkan kepuasan. Kepuasan pelanggan ini bisa menjadi kunci keberhasilan sebuah institusi. Azwar (1996:32) berpendapat bahwa suatu institusi dikatakan berkualitas ketika mampu mempertahankan kualitas input, proses, dan output.

Lembaga pendidikan tinggi (Perguruan Tinggi) dapat dikatakan berkualitas ketika mampu memberikan layanan yang sangat baik kepada siswa dan pemangku kepentingan eksternal. Perguruan tinggi harus mampu memenuhi semua komponen Tri Dharma Perguruan Tinggi mulai dari pendidikan dan pembelajaran, penelitian dan pengabdian kepada masyarakat 
Evaluasi juga dilakukan terhadap para pendukung tiga tridarma lembaga tersier yang mencakup bidang kelembagaan dan tata kelola, staf pengajar, staf pendidikan, fasilitas dan infrastruktur, teknologi informasi dan komunikasi (TIK), dan kolaborasi. Setiap bidang dievaluasi dalam hal pencapaian indikator kinerja input, proses, output, hasil, dan dampaknya.

Perbaikan yang dilakukan bersifat komprehensif terhadap elemen-elemen terkait di dalamnya, seperti kurikulum, fasilitas dan infrastruktur, pembiayaan, sumber daya manusia (dosen / staf pengajar; karyawan / tenaga kependidikan termasuk pustakawan, asisten laboratorium, teknisi), dan elemen lainnya.

Manajemen lembaga pendidikan dapat diartikan sebagai proses memobilisasi dan mengintegrasikan segala sesuatu, baik personel maupun materi yang ada hubungannya dengan pencapaian tujuan pendidikan. Manajemen pendidikan adalah segala upaya orang-orang yang terlibat dalam proses pencapaian tujuan pendidikan yang terorganisir, terintegrasi dan terkoordinasi secara efektif (Purwanto, 2007:27).

Tabel 1. Pendidikan Tenaga Kependidikan FK Unila

\begin{tabular}{|c|c|c|c|c|c|c|c|}
\hline Tahun & SLTP & SLTA & D-1 & D-3 & S1 & S2 & total \\
\hline 2018 & 2 & 34 & 1 & 14 & 20 & 1 & 72 \\
\hline
\end{tabular}

Sumber: Subbagian Perencanaan dan Kepegawaian FK Unila 2018

Pada tahun 2018, sebagian besar staf pengajar di FK Unila masih di tingkat SMP sebanyak 2 orang, SMA sebanyak 34 orang, D-1 sebanyak 1 orang, dan bahkan ada yang memiliki tingkat diploma. dari tiga (D3) dari 14 orang, level S -1 sebanyak 20 (dua puluh) orang, dan mereka yang memiliki level Master adalah sebanyak 1 (satu) orang.

Sayangnya, kenyataan yang terjadi di lapangan masih ada berbagai masalah, termasuk ASN di FK Unila. Masalah-masalah ini meliputi:

1. dalam memberikan layanan kepada mahasiswa, alumni dan civitas akademika dapat dikatakan belum dimaksimalkan;

2. Tingkat pendidikan ASN dari sebagian besar staf pengajar dan staf kontrak pendidikan di FK Unila memiliki tingkat pendidikan yang terbatas, sehingga mereka perlu menghadiri berbagai pelatihan sehingga kualitas layanan yang diberikan dapat dimaksimalkan;

3. terbatasnya frekuensi pendidikan dan pelatihan yang diberikan kepada pekerja kontrak ASN dan BLU University;

4. terbatasnya jumlah tenaga kependidikan, sehingga setiap kali ada kegiatan di FK Unila, pelayanan kepada mahasiswa, alumni dan masyarakat umum terganggu, karena semua sumber daya manusia dikhususkan untuk acara yang akan dan sedang dilaksanakan;

5. seringnya Dekan, dan Wakil Dekan yang menghadiri acara layanan di dalam dan di luar kota juga menyebabkannya terhambat oleh layanan, waktu yang dibutuhkan untuk menyelesaikan layanan tidak sesuai dengan waktu maksimum yang dinyatakan dalam prosedur kualitas (PM); 
Masalah di atas, menimbulkan beragam persepsi siswa, terutama ketika mereka ingin mendapatkan layanan dari mereka. Hasil penelitian yang dilakukan oleh Gunadi (2017:1) yang menghasilkan temuan bahwa kualitas layanan akan mempengaruhi tingkat kepuasan pelanggan. Hasil penelitian yang dilakukan oleh Ratnamiasih, et al (2012:1) menunjukkan bahwa kualitas layanan maksimum akan dapat meningkatkan kepuasan mereka yang dilayani. Semakin tinggi kualitas layanan, semakin tinggi tingkat kepuasan para pihak yang dilayani. Ini juga konsisten dengan hasil penelitian Saraswati, Hamid dan Topowijono (2015:1) yang mengatakan bahwa ada korelasi yang signifikan antara persepsi kualitas layanan. Semakin baik persepsi, semakin baik penilaian kualitas layanan, dan sebaliknya.

Persepsi yang baik tentang layanan staf pendidikan di FK Universitas Lampung dalam melayani siswa tidak hanya dilihat dari keahlian dan pengetahuan mereka, tetapi juga melalui kondisi emosional mereka. Menurut Shi (2007) dalam Ratnamiasih, et al (2012:15), persepsi akan muncul berdasarkan karakteristik yang ditampilkan oleh orang lain seperti motivasi, sifat, keterampilan, persepsi diri, peran sosial, atau bahasa tubuh, yang menghasilkan efektif atau kinerja yang unggul.

Persepsi siswa tentang layanan yang diberikan oleh staf pendidikan di FK Universitas Lampung adalah proses kognitif yang dialami oleh setiap siswa FK dalam memahami informasi tentang lingkungan mereka, baik melalui penglihatan, pendengaran, penghargaan, perasaan, dan bau. Oleh karena itu penting untuk mengidentifikasi serangkaian faktor yang mempengaruhi persepsi siswa, sehingga siswa sebagai pihak yang dilayani memiliki persepsi yang baik.

Melihat semua masalah dan hasil penelitian sebelumnya (canggih) seperti yang dijelaskan di atas dapat dipahami bahwa kualitas layanan di FK Universitas Lampung sangat dipengaruhi oleh persepsi siswa tentang layanan yang diberikan oleh staf pendidikan.

\section{TINJAUAN PUSTAKA}

Walgito (2003:43) berpendapat bahwa: "Persepsi seseorang adalah proses aktif yang memainkan peran, tidak hanya stimulus (sesuatu yang merangsang respons tertentu) tentang hal itu tetapi juga individu secara keseluruhan dengan pengalaman, motivasi, dan sikapnya. yang relevan dalam merespons stimulus (sesuatu yang merangsang respons tertentu)."

Individu dalam kaitannya dengan dunia luar selalu melakukan pengamatan untuk dapat menafsirkan rangsangan yang diterima dan perangkat sensorik digunakan sebagai penghubung antara individu dan dunia luar. Agar proses pengamatan terjadi, perlu untuk mengamati benda-benda yang cukup baik organ indera dan perhatian adalah langkah pertama dalam persiapan untuk melakukan pengamatan. Persepsi dalam pengertian umum adalah pandangan seseorang tentang sesuatu yang akan membuat respons terhadap bagaimana dan dengan apa seseorang akan bertindak.

Sobur (2010:445) menjelaskan, persepsi dalam arti sempit adalah, "Visi, bagaimana seseorang melihat sesuatu; sedangkan dalam arti luas adalah pandangan atau pemahaman, yaitu bagaimana seseorang memandang atau menafsirkan sesuatu." 
CENDEKIA, Vol. 14 No. 1 April 2020

p ISSN: 1978 2098; e ISSN: 2407 8557

Https://soloclcs.org; Email: cendekiaoslo@gmail.com

Center of Language and Cultural Studies, Surakarta, Indonesia

Juriyah, Siti; Yulianto \& Duadji, Noverman. (2020). Pengaruh Dimensi Eksternal Persepsional terhadap Kualitas Layanan Fakultas di Universitas Lampung.

Cendekia (2020), 14(1): 51 62. DOI: 10.30957/cendekia.v14i1.610.

Azzahy (2008:23) persepsi dalam arti sempit adalah, "Visi, yaitu bagaimana seseorang melihat sesuatu; sedangkan dalam arti luas." Persepsi adalah pandangan, yaitu, "Bagaimana seseorang memahami atau menafsirkan sesuatu." Menurut Sobur (2010:37) persepsi dalam arti sempit adalah, "Visi, bagaimana seseorang melihat sesuatu sementara dalam arti luas adalah pandangan atau visi, itulah cara seseorang melihat atau menafsirkan sesuatu."

Azzahy (2008:27) mendefinisikan persepsi sebagai, "Proses mengetahui atau mengenali objek dan peristiwa objektif melalui indera." Persepsi Iksan (2012:34) adalah, "Proses ketika kita menjadi sadar akan banyak rangsangan (sesuatu yang merangsang respons tertentu) yang memengaruhi indera kita."

Organisme atau individu dalam memegang persepsi muncul masalah apa yang dirasakan pertama, apakah bagian dirasakan pertama, maka keseluruhan, atau keseluruhan dirasakan pertama dan kemudian bagian. Dalam hal ini ada dua teori yang berbeda satu sama lain, atau bahkan dapat dikatakan kontradiktif dalam hal persepsi ini, yaitu 1) teori elemen, dan 2) teori Gestalt.

Menurut teori elemen, pada individu yang merasakan sesuatu maka apa yang dirasakan pertama adalah bagian, kemudian keseluruhan. Menurut teori ini, persepsi adalah yang kedua. Jadi, jika seseorang mempersepsikan sesuatu, maka yang dirasakan pertama adalah bagian-bagiannya, kemudian keseluruhannya. Dalam hal ini dapat dikatakan bahwa pada seseorang yang merasakan sesuatu bagian-bagiannya adalah yang utama, sedangkan keseluruhannya adalah bagian yang kedua.

Iksan (2012:56) menyatakan bahwa, "Persepsi dipengaruhi oleh berbagai faktor, termasuk faktor belajar, motivasi, dan pengamat persepsi atau persepsi ketika proses persepsi terjadi. Dan karena ada beberapa faktor subjektif yang mempengaruhi, kesan masing-masing setiap orang akan berbeda satu sama lain. "

Persepsi individu dipengaruhi oleh faktor fungsional dan struktural. Faktor fungsional adalah faktor yang bersifat pribadi. Misalnya kebutuhan individu, usia, pengalaman masa lalu, kepribadian, jenis kelamin, dan hal-hal lain yang subyektif. Faktor struktural adalah faktor di luar individu, misalnya lingkungan, budaya, dan norma sosial sangat berpengaruh pada seseorang dalam mempersepsikan sesuatu.

Faktor eksternal yang memengaruhi persepsi adalah karakteristik lingkungan dan objek yang terlibat di dalamnya. Elemen-elemen ini dapat mengubah perspektif seseorang tentang dunia di sekitarnya dan memengaruhi cara seseorang merasakan atau menerimanya. Sedangkan faktor eksternal yang mempengaruhi persepsi adalah: a) ukuran dan penempatan objek atau rangsangan (sesuatu yang merangsang respons tertentu). Faktor ini menyatakan bahwa semakin besar hubungan suatu objek, semakin mudah untuk dipahami. Bentuk ini akan memengaruhi persepsi individu dan dengan melihat bentuk ukuran suatu objek individu, akan mudah diperhatikan pada gilirannya membentuk persepsi; b) Warna benda. Objek yang memiliki lebih banyak cahaya, akan lebih mudah dipahami (dipersepsikan) dibandingkan dengan yang lebih sedikit; c) Keunikan dan kontras stimulus (sesuatu yang merangsang respons tertentu). Stimulus eksternal yang penampilannya dengan latar belakang dan lingkungannya sepenuhnya di luar asumsi orang lain akan menarik banyak perhatian; d) Intensitas dan kekuatan 
CENDEKIA, Vol. 14 No. 1 April 2020

p ISSN: 1978 2098; e ISSN: 2407 8557

Https://soloclcs.org; Email: cendekiaoslo@gmail.com

Center of Language and Cultural Studies, Surakarta, Indonesia

Juriyah, Siti; Yulianto \& Duadji, Noverman. (2020). Pengaruh Dimensi Eksternal Persepsional terhadap Kualitas Layanan Fakultas di Universitas Lampung.

Cendekia (2020), 14(1): 51 62. DOI: 10.30957/cendekia.v14i1.610.

stimulus (sesuatu yang merangsang respons tertentu). Stimulus dari luar akan memberi makna lebih jika diperhatikan lebih dari apa yang hanya dilihat sekali. Kekuatan rangsangan adalah kekuatan suatu benda yang dapat memengaruhi persepsi; emosi. Individu akan lebih memperhatikan objek yang memberikan pergerakan dalam rentang tampilan dibandingkan dengan objek diam. d) Intensitas dan kekuatan stimulus (sesuatu yang merangsang respons tertentu). Stimulus dari luar akan memberi makna lebih jika diperhatikan lebih dari apa yang hanya dilihat sekali. Kekuatan rangsangan adalah kekuatan suatu benda yang dapat memengaruhi persepsi; emosi. Individu akan lebih memperhatikan objek yang memberikan pergerakan dalam rentang tampilan dibandingkan dengan objek diam. d) Intensitas dan kekuatan stimulus (sesuatu yang merangsang respons tertentu). Stimulus dari luar akan memberi makna lebih jika diperhatikan lebih dari apa yang hanya dilihat sekali. Kekuatan rangsangan adalah kekuatan suatu benda yang dapat memengaruhi persepsi; emosi. Individu akan lebih memperhatikan objek yang memberikan pergerakan dalam rentang tampilan dibandingkan dengan objek diam.

Menurut Sampara dalam Nawawi (2003:5) layanan adalah, "Suatu kegiatan atau urutan kegiatan yang terjadi dalam interaksi langsung antara seseorang dengan orang lain atau mesin secara fisik, dan memberikan kepuasan pelanggan. Berdasarkan berbagai pendapat di atas, peneliti menyimpulkan bahwa layanan adalah kegiatan yang dilakukan oleh seseorang atau sekelompok orang untuk memenuhi kebutuhan orang lain sesuai dengan prosedur dan sistem yang telah ditentukan. "

Gunadi (2017:5) menjelaskan bahwa layanan adalah, "Suatu kegiatan yang ditawarkan oleh suatu organisasi atau individu kepada pengguna yang tidak berwujud, tidak dapat dimiliki dan merupakan tindakan nyata. Layanan atau layanan tidak berwujud hanya dapat dirasakan yang sangat berbeda dari produk berwujud. .

Kotler dalam Gunadi (2017:5) menjelaskan bahwa "Suatu layanan adalah tindakan atau kinerja apa pun yang dapat ditawarkan satu pihak kepada pihak lain yang pada dasarnya tidak berwujud dan tidak mengakibatkan kepemilikan apa pun. Produksinya mungkin atau mungkin tidak terkait dengan produk fisik "Layanan adalah tindakan atau tindakan yang dapat dilihat atau dirasakan manfaatnya dan tidak berakhir dengan kepemilikan sesuatu. Produk dapat dalam bentuk produk fisik atau non-fisik.

Azwar (dalam Astuti, 2012:3) menyatakan bahwa, "Kualitas layanan adalah multi-dimensi, yaitu kualitas menurut pengguna layanan kesehatan dan menurut penyedia layanan kesehatan." kemampuan petugas (dalam hal ini klinik kesehatan) dalam memenuhi kebutuhan pasar dan komunikasi pasien termasuk sifat ramah, bantuan personil dan keseriusan. Selanjutnya, dari penyedia layanan (dalam hal ini klinik kesehatan), kualitas layanan terkait dengan penggunaan sesuai dengan perkembangan ilmu pengetahuan dan teknologi. Secara umum dapat dirumuskan bahwa batas layanan kesehatan yang berkualitas adalah layanan kesehatan yang dapat memuaskan setiap pengguna layanan sesuai dengan tingkat kepuasan rata-rata penduduk, serta implementasinya sesuai dengan kode etik dan standar yang ditetapkan. 


\section{METODE}

Jenis penelitian ini adalah penelitian korelasional. Data dikumpulkan dengan menggunakan teknik kuesioner yang diberikan kepada 91 sampel dari populasi 771 mahasiswa Fakultas Kedokteran Universitas Lampung. Pengambilan sampel menggunakan teknik proporsional stratified random sampling sebanyak $10 \%$ untuk setiap gaya. Data dianalisis menggunakan metode statistik inferensial dengan regresi linier. Pengujian hipotesis dilakukan dengan menggunakan perangkat lunak statistik SPSS Versi 19.0.

\section{HASIL}

Visi FK Unila: "Fakultas Kedokteran Universitas Lampung menjadi Sepuluh Fakultas Kedokteran Terbaik di Indonesia pada tahun 2025 dengan Spesialisasi Agromedis".

Untuk mewujudkan visi Fakultas Kedokteran, Unila, Misi Fakultas Kedokteran telah didirikan yang selaras dengan Misi Universitas Lampung dan Misi Pendidikan Nasional. Misi Fakultas Kedokteran Unila, yaitu:

1. Mewujudkan organisasi Pendidikan Tinggi Tri Dharma berkualitas tinggi dengan kekhususan agromedis

2. Menghasilkan lulusan yang Profesional dan Beretika;

3. Mewujudkan tata kelola organisasi yang dapat memberikan kualitas layanan;

4. Mewujudkan Publik pendidikan dokter yang terjangkau dan adil;

5. Meningkatkan kualitas sumber daya manusia baik dosen maupun staf kependidikan dan daya saing;

6. Meningkatkan fasilitas dan infrastruktur yang mendukung implementasi Tri Dharma College;

7. Mewujudkan kerjasama dengan berbagai pihak pendukung organisasi Tri Dharma Perguruan Tinggi.

Saat ini, FK Unila sedang berusaha untuk menjadi program studi yang unggul yang merupakan pilihan pertama bagi calon mahasiswa. Untuk menanggapi penggemar yang telah meningkat secara signifikan setiap tahun, perlu ada peningkatan layanan kepada siswa. Oleh karena itu, parameter pengukuran yang digunakan sebagai tolok ukur untuk kualitas layanan adalah kurikulum, fasilitas dan infrastruktur, serta kualitas sumber daya manusia itu sendiri.

Kurikulum yang diterapkan di FK Unila mengacu pada Kurikulum Berbasis Kompetensi (KBK) untuk pendidikan kedokteran. Berdasarkan Standar Kompetensi Dokter Indonesia (SKDI), kurikulum FK dibagi menjadi 7 semester untuk program Sarjana Kedokteran, dengan total 160 kredit dan 90 minggu untuk program Dokter Profesional dengan sebanyak 54 kredit (Peraturan Akademik, FK Unila, 2017:13).

Pengujian hipotesis diperlukan untuk review menentukan apakah ADA pengaruh ANTARA SEMUA variabel Tbk Terhadap kualitas layanan di Fakultas Kedokteran Universitas Lampung, Yang disajikan ditunjukan kepada Siswa Sesuai dengan penelaian Siswa. Untuk Menguji hipotesis digunakan rumus regresi linier sederhana Dan 
berganda. Berdasarkan perhitungan analisis data yang SPSS hasil temuan berikut TIMAH.

Meja 2. Hasil Analisis Uji Regresi

\begin{tabular}{|l|l|l|l|l|}
\hline TIDAK. & TIDAK. & TIDAK. & TIDAK. Deskripsi & TIDAK. \\
Deskripsi Nilai & Deskripsi & Deskripsi & Nilai F Tingkat & Deskripsi \\
F Tingkat & Nilai F & Nilai F & signifikansi & Nilai F \\
signifikansi & Tingkat & Tingkat & KESIMPULAN & Tingkat \\
KESIMPULA & signifikansi & signifikansi & & signifikansi \\
N & KESIMPUL & KESIMPUL & & KESIMPUL \\
& AN & AN & & AN \\
\hline 1 & Regresi X1-Y & 43,402 & $.000 \mathrm{a}$ & Penting \\
\hline 2 & Regresi X2-Y & 46,118 & $.000 \mathrm{a}$ & Penting \\
\hline 3 & Regresi X3-Y & 135,589 & $.000 \mathrm{a}$ & Penting \\
\hline 4 & Regresi X4-Y & 204,769 & $.000 \mathrm{a}$ & Penting \\
\hline 5 & Regresi X5-Y & 139,128 & $.000 \mathrm{a}$ & Penting \\
\hline 7 & Regresi X1- & 51,940 & $.000 \mathrm{a}$ & Penting \\
\hline
\end{tabular}

Sumber: Hasil Pemrosesan data PADA Tahun 2018

Berdasarkan hasil temuan analisis uji regresi Nilai atau koefisien F hitung (X1-Y) sebesar 43.402 dan Nilai Probabilitas 0,000<0,05. Mencari Google Artikel Nilai-Nilai Suamimenunjukkan bahwa Peralatan untuk review LAYANAN Beroperasi signifikan mempengaruhi kualitas layanan di Fakultas Kedokteran di Universtias Lampung.

Koefisien F Yang dihitung (X2-Y) Adalah 46.118 Dan Nilai Probabilitas 0,000 $<0,05$. Mencari Google Artikel Nilai-Nilai Suamimenunjukkan bahwa warna objek telah dipakai LAYANAN Beroperasi signifikan mempengaruhi kualitas layanan di Fakultas Kedokteran Universitas Lampung.

Koefisien F Yang dihitung (X3-Y) Adalah 135,589 Dan Nilai Probabilitas 0,000 $<0,05$. Mencari Google Artikel Nilai-Nilai Suamimenunjukkan bahwa keunikan atau KontraS Dari stimulus karyawan Beroperasi signifikan mempengaruhi kualitas layanan di Fakultas Kedokteran Universitas Lampung.

Koefisien F Yang dihitung (X4-Y) Adalah 204.769 Dan Nilai Probabilitas 0,000 $<0,05$. Mencari Google Artikel Nilai-Nilai Suamimenunjukkan bahwa gaya individu hearts menarik Perhatian Siswa Beroperasi signifikan mempengaruhi kualitas layanan di Fakultas Kedokteran Universitas Lampung.

Koefisien F Yang dihitung (X5-Y) Adalah 139,128 Dan Nilai Probabilitas 0,000 $<0,05$. Mencari Google Artikel Nilai-Nilai Suamimenunjukkan bahwa Gerakan atau Pergerakan layanan Beroperasi signifikan mempengaruhi kualitas layanan di Fakultas Kedokteran di Universtias Lampung.

Koefisien F Yang dihitung (X1,2,3,4,5, Y) Adalah 51.940 Dan Nilai Probabilitas $0,000<0,05$. Mencari Google Artikel Nilai-Nilai Suamimenunjukkan bahwa peralatan untuk layanan, warna objek layanan, keunikan atau kontras stimulus, gaya individu 
menarik perhatian, dan gerakan atau gerakan layanan memiliki pengaruh signifikan terhadap kualitas layanan di Fakultas Kedokteran di Universtias Lampung

Untuk memastikan signifikan atau tidaknya pengaruh persepsi siswa terhadap kualitas layanan juga dapat dilihat dengan uji t.

Tabel 3. hasil analisis uji t

\begin{tabular}{|l|l|l|l|l|}
\hline Tidak. & Deskripsi & Nilai T & $\begin{array}{l}\text { Hitung tingkat } \\
\text { signifikansi }\end{array}$ & kesimpulan \\
\hline 1 & Regresi X1-Y & 6.588 & $.000 \mathrm{a}$ & Penting \\
\hline 2 & Regresi X2-Y & 6,791 & $000 \mathrm{a}$ & Penting \\
\hline 3 & Regresi X3-Y & 11.644 & $000 \mathrm{a}$ & Penting \\
\hline 4 & Regresi X4-Y & 14,310 & $000 \mathrm{a}$ & Penting \\
\hline 5 & Regresi X5-Y & 11.795 & $000 \mathrm{a}$ & Penting \\
\hline 7 & Regresi X1-6-Y & 2644 & 0010 & Penting \\
\hline
\end{tabular}

Sumber: Hasil Pengolahan Data di 2018

Hipotesis pengujian kriteria adalah menolak $\mathrm{H} 0$ jika $\mathrm{t}>\mathrm{t}$ tabel dan sebaliknya. Untuk distribusi t digunakan, ia memiliki derajat kebebasan (df) atau juga disebut derajat kebebasan $(\mathrm{dk}) ; \mathrm{dk}=(\mathrm{n}-2)$ dan tingkat signifikan 0,05 .

Berdasarkan analisis data diketahui bahwa arti dari semua perhitungan di $<0,05$ dengan demikian, semua $\mathrm{H} 0$ ditolak dan semua $\mathrm{H} 1$ diterima, sehingga dapat disimpulkan bahwa ada pengaruh yang signifikan antara peralatan untuk layanan, warna layanan benda, keunikan atau kontras dari stimulus, individu kekuatan dalam menarik perhatian, dan gerak atau gerakan pelayanan terhadap kualitas layanan baik secara parsial maupun secara simultan (bersama-sama). berikut.

Kontribusi persepsi mahasiswa kualitas pelayanan dapat ditabulasikan sebagai

Tabel hasil analisis 4. Korelasi

\begin{tabular}{|c|c|c|c|c|}
\hline Model & $\begin{array}{l}\text { Nilai R } \\
\text { calcute }\end{array}$ & nilai R2 & $\begin{array}{l}\text { Nilai R2 } \\
\text { menyesuaikan }\end{array}$ & $\begin{array}{l}\text { Diperkirakan } \\
\text { kesalahan }\end{array}$ \\
\hline Ry1 & 0573 & 0328 & 0320 & 18.876 \\
\hline Ry2 & 0584 & 0341 & 0334 & 18.685 \\
\hline Ry3 & 0777 & 0604 & 0599 & 14.493 \\
\hline Ry4 & 0835 & 0697 & 0694 & 12.672 \\
\hline Ry5 & 0871 & 0610 & 0605 & 14.380 \\
\hline Ry1,2,3,4,5 & 0868 & 0753 & 0739 & 11.699 \\
\hline
\end{tabular}

Sumber: Hasil Pengolahan Data di 2018

Berdasarkan hasil product moment analisis XY1 korelasi, koefisien R dihitung dari 0,573 diperoleh, nilai $\mathrm{R}$ squared adalah 0,328 atau 32,8\%. Jadi dapat disimpulkan bahwa peralatan untuk layanan kontribusi terhadap kualitas pelayanan sebesar 32,8\%. Sisanya $61,2 \%$ ditentukan oleh variabel lain yang tidak diteliti melalui studi ini. 
CENDEKIA, Vol. 14 No. 1 April 2020

p ISSN: 1978 2098; e ISSN: 2407 8557

Https://soloclcs.org; Email: cendekiaoslo@gmail.com

Center of Language and Cultural Studies, Surakarta, Indonesia

Juriyah, Siti; Yulianto \& Duadji, Noverman. (2020). Pengaruh Dimensi Eksternal Persepsional terhadap Kualitas Layanan Fakultas di Universitas Lampung.

Cendekia (2020), 14(1): 51 62. DOI: 10.30957/cendekia.v14i1.610.

Produk Xy2 analisis korelasi momen diperoleh koefisien $\mathrm{R}$ dihitung dari 0,584, nilai $\mathrm{R}$ kuadrat dari 0.341 , atau $34,1 \%$. Jadi dapat disimpulkan bahwa warna dari objek layanan berkontribusi terhadap kualitas pelayanan dengan $65,9 \%$. Sisanya $31,1 \%$ ditentukan oleh variabel lain yang tidak diteliti melalui penelitian ini.

Produk Xy3 analisis korelasi momen diperoleh koefisien $\mathrm{R}$ dihitung dari 0.777 , nilai $\mathrm{R}$ kuadrat dari 0,604 , atau $60,4 \%$. Jadi dapat disimpulkan bahwa keunikan atau kontras memberikan kontribusi stimulus untuk kualitas layanan dengan 60,4\%. Sisanya $39,6 \%$ ditentukan oleh variabel lain yang tidak diteliti melalui studi ini.

produk Xy4 analisis korelasi momen diperoleh koefisien $\mathrm{R}$ dihitung dari 0,835 , nilai $\mathrm{R}$ kuadrat dari 0,697 , atau $69,7 \%$. Jadi dapat disimpulkan bahwa gaya individu dalam menarik perhatian kontribusi terhadap kualitas pelayanan dengan $69,7 \%$. Sisanya $30,3 \%$ ditentukan oleh variabel lain yang tidak diteliti melalui studi ini.

Produk Xy5 analisis korelasi momen diperoleh koefisien $\mathrm{R}$ dihitung dari 0,872, nilai $\mathrm{R}$ kuadrat dari 0,610 , atau $61,0 \%$. Jadi dapat disimpulkan bahwa gerakan gerakan atau layanan kontribusi terhadap kualitas pelayanan dengan $61,0 \%$. Sisanya 39,0\% ditentukan oleh variabel lain yang tidak diteliti melalui studi ini.

Analisis koefisien korelasi product moment Xy 1,2,3,4,5 diperoleh $\mathrm{R}$ dari 0,868, $\mathrm{R}$ persegi 0,753 , atau $75,3 \%$. Jadi dapat disimpulkan bahwa suasana hati sementara yang melayani kontribusi terhadap kualitas pelayanan dengan $75,3 \%$. Sisanya $24,7 \%$ ditentukan oleh variabel lain yang tidak diteliti melalui studi ini.

\section{PEMBAHASAN}

Ketika ingin meningkatkan kualitas layanan sesuai dengan penilaian siswa, persepsi siswa staf pendidikan di Fakultas Kedokteran perlu ditingkatkan, dengan tetap berpegang pada peraturan, jam pelayanan, dan Prosedur Standar Operasional (PSO/ SOP).

Kondisi seperti itu juga sesuai dengan pendapat Sobur (2010:445) menjelaskan, persepsi dalam arti sempit adalah visi, bagaimana seseorang melihat hal; sedangkan dalam arti luas adalah pandangan atau pemahaman, yaitu bagaimana seseorang mempersepsikan atau menafsirkan sesuatu. Jadi, ketika mereka ingin meningkatkan persepsi siswa, segala sesuatu yang dilihat atau terlihat oleh siswa harus mampu memberikan kesan yang baik atau penilaian. Dampak dari langkah ini adalah peningkatan persepsi siswa tentang kualitas layanan yang diterima.

Jika kita mendengarkan pendapat Thomas (2013:76) yang mengatakan bahwa persepsi adalah suatu proses yang kompleks yang menyebabkan orang untuk menerima atau meringkas informasi yang diperoleh dari lingkungan mereka. Semuanya selalu dimulai dengan persepsi, yaitu setelah menerima stimulus (sesuatu yang merangsang respon tertentu) atau pola stimulasi dari lingkungan. Dengan begitu, ketika siswa ingin informasi menyimpulkan diperoleh dari lingkungan mereka, staf pendidikan yang menyediakan layanan harus dapat memberikan informasi atau tayangan yang positif kepada siswa.

Demikian hasil studi ini mendukung pendapat Suparyanto (2011: 24) yang mengatakan bahwa persepsi adalah proses akhir dari pengamatan yang dimulai oleh 
CENDEKIA, Vol. 14 No. 1 April 2020

p ISSN: 1978 2098; e ISSN: 2407 8557

Https://soloclcs.org; Email: cendekiaoslo@gmail.com

Center of Language and Cultural Studies, Surakarta, Indonesia

Juriyah, Siti; Yulianto \& Duadji, Noverman. (2020). Pengaruh Dimensi Eksternal Persepsional terhadap Kualitas Layanan Fakultas di Universitas Lampung.

Cendekia (2020), 14(1): 51 62. DOI: 10.30957/cendekia.v14i1.610.

penginderaan, yaitu proses menerima stimulus oleh indera, maka individu memiliki perhatian dan diteruskan ke otak, maka menyadari individu tentang keberadaan sesuatu melalui persepsi individu sadar dan bisa mengerti tentang keadaan lingkungan di sekitar mereka dan tentang hal-hal yang ada pada individu yang bersangkutan. Dengan demikian, ketika staf pendidikan ingin meningkatkan siswa persepsi, stimulus yang akan diterima oleh siswa organ sensorik harus optimal ditingkatkan, karena stimulus tersebut akan diteruskan ke otak siswa sehingga penilaian yang baik dari layanan yang diterima oleh siswa tumbuh .

Untuk keyakinan asuh, juga dapat disebut pendapat Mar'at (1991:34) yang menyatakan bahwa proses persepsi adalah proses kognitif yang dipengaruhi oleh pengalaman individu, wawasan, dan pengetahuan. Demikian juga dalam pembentukan persepsi, perlu untuk memproses kognisi yang dilakukan oleh staf pendidikan sehingga kesan, pengalaman, wawasan dan pengetahuan siswa tumbuh ke arah membentuk persepsi yang baik dari kualitas pelayanan yang mereka terima.

Kondisi di atas pada dasarnya sesuai dengan pendapat Mar'at (1991:35) yang mengatakan bahwa proses pembentukan persepsi sebagai arti dari pengamatan dimulai dengan kehadiran rangsangan. Setelah mendapatkan rangsangan, langkah berikutnya adalah pemilihan yang berinteraksi dengan proses seleksi. Proses seleksi terjadi ketika informasi seseorang memperoleh, maka proses pesan memilih akan berlangsung tentang yang pesan dianggap penting dan tidak penting. Demikian juga tentang pembentukan persepsi siswa tentang layanan di FK Unila, maka persepsi ini bisa dibentuk setelah siswa melakukan pengamatan pada stimulus yang diberikan oleh penyedia layanan dalam hal ini staf pendidikan. stimulus kemudian berinteraksi dengan kegiatan seleksi yang dilakukan oleh siswa dalam bentuk pemilihan yang baik dan layanan yang tidak menguntungkan. Ketika hasil seleksi menunjukkan bahwa baik layanan mendominasi pengamatan, maka persepsi mereka akan menjadi baik, dan sebaliknya, ketika hasil seleksi menunjukkan bahwa layanan buruk mendominasi pengamatan, maka persepsi mereka akan buruk juga.

Terkait dengan faktor-faktor yang mempengaruhi persepsi menurut Robbins (2003:56) pada dasarnya dibagi menjadi 2 Faktor yaitu internal dan Faktor Eksternal. Demikian juga dalam kaitannya dengan persepsi FK siswa, hal ini juga dipengaruhi oleh faktor-faktor eksternal yang mereka merasa seperti kondisi ruang layanan, kenyamanan, sarana dan prasarana, kelincahan (gerak), dan kemampuan staf pendidikan, dan sebagainya.

Hal ini konsisten dengan temuan penelitian Shi (2007 Ratnamiasih, et al (2012:3), yang mengatakan bahwa persepsi akan terjadi berdasarkan karakteristik yang ditampilkan oleh orang lain seperti motivasi, sifat, keterampilan, persepsi diri, peran sosial, atau bahasa tubuh, yang menghasilkan kinerja yang efektif atau superior.

Seluruh uraian di atas, menghasilkan pemahaman bahwa persepsi siswa tentang kualitas layanan yang diberikan oleh staf pendidikan di Fakultas Kedokteran Universitas Lampung dapat dipahami sebagai suatu proses di mana individu mengatur dan menginterpretasikan rasa akal dalam memberikan makna lingkungan mereka. Dengan demikian, persepsi siswa tentang kualitas layanan yang diberikan oleh staf 
pendidikan di FK Universitas Lampung pada umumnya adalah proses bagaimana siswa pilih, mengatur, dan menafsirkan berbagai layanan yang mereka terima sampai mereka diterima sebagai masukan informasi sehingga tercipta gambaran keseluruhan untuk layanan yang mereka telah mendapatkan. Jadi, salah satu faktor yang menyebabkan seseorang harus puas dalam menerima pelayanan karena mereka memiliki persepsi yang baik tentang kualitas layanan yang diberikan sejauh ini.

\section{SIMPULAN}

Berdasarkan hasil analisis data dan pembahasan dapat disimpulkan bahwa:

1. ada pengaruh yang signifikan antara peralatan untuk layanan pada kualitas layanan di Universitas Fakultas Kedokteran

2. ada pengaruh yang signifikan antara warna dari objek dari layanan pada kualitas layanan di Fakultas Kedokteran Universitas

3. ada pengaruh yang signifikan antara keunikan atau kontras dari stimulus untuk kualitas layanan di Universitas Fakultas Kedokteran

4. ada pengaruh yang signifikan antara gaya individu dalam menarik perhatian terhadap kualitas layanan di Universitas Fakultas Kedokteran

5. ada pengaruh yang signifikan antara gerak atau layanan gerakan pada kualitas pelayanan di Fakultas Kedokteran Universitas

6. ada variasi bersama antara peralatan untuk layanan, warna objek layanan, keunikan atau kontras stimulus, gaya individu menarik perhatian, dan gerakan atau gerakan dari layanan untuk kualitas layanan di Universitas Fakultas Kedokteran

\section{DAFTAR PUSTAKA}

Astuti, Wiji. 2012. Analisis Kualitas Pelayanan Rumah Sakit Rawat Inap Mardi Waluyo (RSMW), Kota Metro. Skripsi. Bandar Lampung. Universitas Lampung

Azwar, Azrul. 1996. Mempertahankan Kualitas Pelayanan Kesehatan. Jakarta: Sinar Harapan

Azzahy, Ghana Syakira. 2008. Persepsi Tentang. On line:http://syakirablog.blogspot.com/2008/11/tentang-persepsi.html diakses Tanggal 5 Februari 2018

Gunadi. 2017 "Quality of Service sebagai Variabel Intervensi Antara Kompetensi Karyawan dan Budaya Kerja dan Kepuasan Mitra di One-Stop Layanan Terpadu dari Free Trade Zone dan Batam Badan Manajemen Free Trade Zone. . "Hasil Penelitian Batam: FE Universitas Batam.

Ikhsan, Khairul. 2012. Konsep PerceptionOnline:http://khairuliksan.blogspot.com/2012/11/konsep-persepsi 19.html Diakses Tanggal 3 Februari 2018

Mar'at, 1991. Sikap Manusia Perubahan Dan Its Pengukuran. Jakarta: Ghalia Indonesia. Nawawi, Hadari. 2003. Manajemen Sumber Daya Manusia untuk Businesses. Yogyakarta Kompetitif: Gadjah Mada University Press 
Ratnamiasih, Ina, dkk. 2012. Kepemimpinan, Organisasi Control, dan Keselamatan Kerja dan Dampak Terhadap Kualitas Pelayanan Rumah Sakit di Bandung. On line:https://www.researchgate.net/publication/ diakses Tanggal 1 Juli 2018

Robbins, Stephen P. 2003. Organisasi perilaku. Jakarta: Indeks

Saraswati, AB, Hamid Dan Topowijono. 2015. Pengaruh Pelatihan Kompetensi

Karyawan dan Kualitas Pelayanan (Studi pada Eco Green Park, Batu) .Jurnal Administrasi Bisnis (JAB) | Vol. 23 No. 2 Juni 2015

Sobur, Alex. 2010. Psikologi Umum. Yogyakarta; Pustaka Setia

Suparyanto, 2011. Konsep Persepsi. On line:http://dr-

suparyanto.blogspot.com/2011/07/konsep-persepsi.html

Thomas, M. 2013. Prinsip dan Praktek heterogen Katalisis, VCH, Weinheim. On

line:https://onlinelibrary.wiley.com diakses Tanggal 6 Februari 2018

Walgito, Bimo, 2003. Pengantar Umum Psikologi, Yogyakarta: ANDI. 